\title{
Characteristics of Coronary Artery Disease Patients Who Have a Polymorphism in the Cholesterol Ester Transfer Protein (CETP) Gene
}

\author{
GÜLIZ DIRIMEN ARIKAN ${ }^{1}$, SELIM ISSBIR $^{2}$, SEDA GÜLEÇ YILMAZ ${ }^{3}$ and TURGAY ISBIR ${ }^{4}$ \\ ${ }^{1}$ Nursing Department, Faculty of Health Sciences, Yeditepe University, Istanbul, Turkey; \\ ${ }^{2}$ Department of Cardiovascular Surgery, Marmara University Pendik Education and Research Hospital, Istanbul, Turkey; \\ ${ }^{3}$ Department of Molecular Medicine, Institute of Health Sciences, Yeditepe University, Istanbul, Turkey; \\ ${ }^{4}$ Department of Medical Biology, Faculty of Medicine, Yeditepe University, Istanbul, Turkey
}

\begin{abstract}
Background/Aim: Cholesterol ester transfer protein $(C E T P)$ is responsible for the transformation of high density lipoprotein $(H D L)$ to low density lipoprotein $(L D L)$ and is a risk factor for atherosclerosis. Our study investigated the association of the rs5883 CETP gene polymorphism with $H D L$ and $L D L$ levels, in 45 coronary artery disease patients and 45 control patients. Materials and Methods: CETP gene polymorphism was detected using Real Time-Polymerase Chain Reaction (RT-PCR). Lipoprotein levels were measured using Quantimetrix system. Results: There were lack of associaition regarding CETP polymorphism in atherosclerosis and HDL and LDL levels ( $p>0.05)$ BMI was higher among coronary artery disease patients $(C A D P)$ compared to the control group $(28.97 \pm 6.38,26.52 \pm 4.39$ respectively, $p<0.03)$. Frequency of $C A D P(82.6 \%, n=19)$ who were taking treatment was higher $(17.4 \%, n=4)(p<0.00)$. The frequencies of hypertension and type-2 diabetes were higher among $C A D P$ $(p<0.00)$. Families of CADP have more CADP $(p<0.02)$. Small HDL particle levels were higher in the control group $(p<0.00)$. Conclusion: In Turkey, BMI, and frequencies of hypertension and type-2 diabetes were higher among CADP than among healthy controls. Furthermore, the genotypes of the rs5883 CETP gene polymorphism did not differ between $C A D P$ and healthy controls.
\end{abstract}

This article is freely accessible online.

Correspondence to: Güliz Dirimen Arikan, Asist. Prof., MD, PhD. Yeditepe University Faculty of Health Sciences, Istanbul, Turkey. Tel: +90 2165780000, Ext. 3255, e-mail: guliz.dirimen@yeditepe.edu.tr, gulizdirimen@yahoo.co.uk

Key Words: Cholesterol ester transfer protein, polymorphism, atherosclerosis, coronary artery disease, real-time PCR.
Cardiovascular diseases (CVD) are still one of the main causes of mortality around the world and contributes to nearly $80 \%$ of disease burden in developed countries (1-3). According to data from the World Health Organisation (WHO), 17 million people die of CVD every year, especially of myocardial infarction (MI) and stroke (4). In The Health Statistics Report of WHO for 2015, mortality rates in Turkey in 2012 were about $5.5 \%$ (5). In 2008, in the study of Tokgözoğlu et al., the prevalence of atherosclerotic diseases was found high among the young population with a mean age of 29 years old (6).

Molecular studies have shown that cholesterol ester transfer protein (CETP) is associated with high density lipoprotein (HDL) metabolism and atherosclerosis. CETP is responsible for the transformation of HDL to low density lipoprotein (LDL) and therefore, it is a risk factor for atherosclerosis (7). It has been shown that many single nucleotide polymorphisms (SNP) of the CETP gene are related to its protein levels and activity and HDL-cholesterol (8).

CETP gene includes 16 exons and 15 introns (9) in the 16q12-16q21 gene locus and is appoximately $25 \mathrm{~kb}(10)$. Genetic studies have indicated that individuals, deficient for or with a mutated CETP gene have high HDL cholesterol levels (11). CETP is a hydrophobic glycoprotein synthesized by hepatocytes and adipocytes $(12,13)$. It is known that CETP expression is induced by hypercholesterolemia associated with nutrition (13). CETP decreases HDL levels by playing a role in the convertion of cholesteryl esters to smaller non-HDL cholesterol, like LDL that is quite atherogenic. While size and triglyceride content of lipoproteins increase, CETP activity increases (12). CETP inhibitors exhibit cardiovascular adverse effects and have not been used. Studies examining the association of CETP gene polymorphisms, LDL, and HDL with the development of atherosclerosis have shown different and conflicting results. Genetic diversity of populations has influenced the results 
(9). In the light of this information, the aim of this study was to investigate the association of CETP gene polymorphisms, HDL, and LDL with coronary artery disease (CAD).

\section{Materials and Methods}

Study participants and clinical investigation. This study was approved by the Clinical Trials Ethical Committee of Yeditepe University. This was a case-control study included totally 90 individuals. The coronary artery disease patient (CADP) group $(n=45)$ consisted of patients who were 18-65 years old, diagnosed using coronary angiography at the Cardiovascular Surgery Clinic of T.C. Ministry of Health Marmara University Pendik Training and Research Hospital. The healthy control group $(n=45)$ consisted of individuals who came to the same unit for check-up, and were 1865 years old without atherosclerosis and/or CAD. After getting informed consent of healthy controls and coronary artery disease patients, blood serum and DNA samples were obtained. The experiments were conducted at Medical Biology Department Laboratory of Yeditepe University Faculty of Medicine.

Genomic DNA isolation. Blood samples were collected in tubes with EDTA (Ethylenediaminetetraacetic acid) and stored at $+4^{\circ} \mathrm{C}$. DNA isolation from peripheral leukocytes was performed using iPrep nucleic acid isolation robot and iPrep PureLink Genomic DNA Blood Kit (Invitrogen, Life Technologies, Carlsbad, CA, USA) according to the manufacturer's protocol.

Genomic DNA purity measurement. The purity and the concentrarion of isolated DNA was measured using Nano2000 spectrophotometry (Thermoscientific, Waltham, MA, USA) and genomic DNA samples with a concentration $>50 \mathrm{ng} / \mu \mathrm{l}$ and purity levels $1.7<\mathrm{A}_{260} / \mathrm{A}_{280}<1.9\left(\mathrm{OD}_{260} / \mathrm{OD}_{280}\right.$ value is between 1.7-1.9) were included in the study (14).

Genotyping analysis with Real Time Polymerase Chain Reaction $(R T-P C R)$. This analysis was done using RT-PCR LightCycler ${ }^{\circledR} 480$ Instrument II (Roche Diagnostics, Mannheim, Germany). Fluorescent probes against two different sequences labeled with differents dyes for wild type allele and mutant allele exist (15). Detection of Cholesterol Ester Transfer Protein (CETP) polymorphism (rs5883) was performed using RT-PCR LightCycler FastStart DNA Master plus SYBR Green I (Roche Diagnostics) following the manufacturer's instructions. The reaction conditions were as follows: denaturation for $10 \mathrm{sec}$ at $95^{\circ} \mathrm{C}, 45$ cycles of amplification for $5 \mathrm{sec}$ at $95^{\circ} \mathrm{C}$, annealing for $10 \mathrm{sec}$ at $57^{\circ} \mathrm{C}$ and extension for $5 \mathrm{sec}$ at $72^{\circ} \mathrm{C}$. After a melting curve step, the reaction ends with cooling at $40^{\circ} \mathrm{C}$ for $10 \mathrm{sec}$. Analysis of fluorescence curves and detection of interception point of samples was applied in order to detect the polymorphism.

LDL and HDL sub-fraction analysis. Blood serum samples were stored at $-20^{\circ} \mathrm{C}$ and the Lipoprint ${ }^{\circledR}$ Lipoprotein Subfractions Testing kits (Quantimetrix Corporation, CA, USA) were stored at $+4^{\circ} \mathrm{C}$. They were left for $2 \mathrm{~h}$ at room temperature before use. Loading gel (photoactive dye) was added into blood serum samples which were loaded in polyacrylamide gel tubes and incubated for $35 \mathrm{~min}$. at white light for polymerization. LDL and HDL sub-fractions were separated using Lipoprint ${ }^{\circledR}$ (Quantimetrix Corporation, CA, USA) closed polyacrylamide gel electrophoresis system. After electrophoresis, images of gel columns were scanned, transferred to the computer, and analyzed via Lipoprint System Research Software (Quantimetrix Corporation, CA, USA) program. The amount of LDL and HDL sub-fractions were measured.

Statistical analysis. SPSS program version 22.0 and 24.0 were used. For the analysis of data, descriptive statistical methods (arithmetic mean, median, standard deviation) were used. Differences between groups were analyzed with paired independent sample Student's $t$-test and Mann-Whitney $U$-test for numerical variables, and with Fisher's exact test and Pearson's chi-square $\left(\chi^{2}\right)$ test for categorical variables. Scores obtained are presented as number (n) and percentage (\%). Results were evaluated at $p<0.05$ statistical significance and $95 \%$ confidence interval. Allele frequencies were detected using a gene counting method.

\section{Results}

A total of 45 healthy controls and 45 CADPs were included in this study. Table I shows the demographical data of the groups. The mean age of the control group was 58.02 \pm 8.75 and 59.01 \pm 10.72 for the CADP group. Although the patients of the CADP group had a higher body weight $(80.89 \pm 15.65)$ compared to the healthy control group $(75.13 \pm 13.41)$, the difference was not statistically significant $(p<0.06)$. The BMI of the CADP group was higher $(28.97 \pm 6.38)$ than that of the control group $(26.52 \pm 4.39)(p<0.03)$. Regarding smoking status, there was no statistical difference between groups $\left(p<0.29, \chi^{2}=1.11\right)$. Regarding cholesterol treatment, it was observed that $82.6 \%$ of CADP $(n=19)$ and $17.4 \%$ of the control group were taking medicine $\left(p<0.00, \chi^{2}=13.14\right)$. Considering medical history, $71.0 \%$ of CADPs $(n=22)$ had hypertension and $75.0 \%$ of them had type 2 diabetes $(n=18)$, while $29.0 \%$ of the control group $(n=9)$ had hypertension and $25.0 \%(\mathrm{n}=6)$ had type 2 diabetes (respectively $p<0.00$, $\left.\chi^{2}=8.31 ; p<0.00, \chi^{2}=8.18\right)$. Regarding family history, it was observed that in the CADP group $(73.7 \%, \mathrm{n}=14)$ a higher number of members had CADP than in the control group $(\mathrm{n}=5,26.3 \%) \quad\left(p<0.02, \chi^{2}=5.40\right)$. Also, there was no statistically significant difference between male and female groups regarding HDL-risk score $(p<0.96)$.

Table II shows the genotypes and allele counts of both groups. It was observed that the $\mathrm{CC}$ and $\mathrm{CT}$ genotypes were balanced among groups and there was no statistically significant difference between groups: CC genotype was seen in $91.1 \%$ of the control group and in $88.9 \%$ of the CADP group; CT genotype was in $8.9 \%$ of the control group and $11.1 \%$ of the CADP group ( $p>1.00$ for both groups). TT genotype was not observed at all.

Considering the distribution of demographical data among the groups according to CETP polymorphism genotypes, there was no statistically significant association between genotype and allele counts of groups and smoking, statin usage, hypertension, Type 2 diabetes and family history 
Table I. The demographical data of groups.

\begin{tabular}{|c|c|c|c|}
\hline Demographical data & $\begin{array}{c}\text { Control } \\
\text { group }(n=45)\end{array}$ & $\begin{array}{c}\text { Coronary artery disease patient } \\
\text { group }(n=45)\end{array}$ & $p$-Value \\
\hline Age (Year) & $58.02 \pm 8.75$ & $9.01 \pm 10.72$ & 0.07 \\
\hline Gender & & & 0.26 \\
\hline Women & $\mathrm{n}=17(58.6 \%)$ & $\mathrm{n}=12(41.4 \%)$ & \\
\hline Men & $\mathrm{n}=28(45.9 \%)$ & $\mathrm{n}=33(73.3 \%)$ & \\
\hline Height $(\mathrm{cm})$ & $168.27 \pm 8.20$ & $167.56 \pm 8.72$ & 0.69 \\
\hline Body Weight (kg) & $75.13 \pm 13.41$ & $80.89 \pm 15.65$ & 0.06 \\
\hline $\mathrm{BMI}^{*}\left(\mathrm{~kg} / \mathrm{m}^{2}\right)$ & $26.52 \pm 4.39$ & $28.97 \pm 6.38$ & $\mathbf{0 . 0 3}$ \\
\hline $\mathrm{BSA}^{* *}\left(\mathrm{~m}^{2}\right)$ & $1.84 \pm 0.18$ & $1.89 \pm 0.18$ & 0.15 \\
\hline Smoking & & & 0.29 \\
\hline Smokers & $\mathrm{n}=20(44.4 \%)$ & $\mathrm{n}=25(55.6 \%)$ & \\
\hline Non-smokers & $\mathrm{n}=25(55.6 \%)$ & $\mathrm{n}=20(44.4 \%)$ & \\
\hline Statin & & & $0.00 *, \mathrm{a}$ \\
\hline Users & $\mathrm{n}=4(17.4 \%)$ & $\mathrm{n}=19(82.6 \%)$ & \\
\hline Non-users & $\mathrm{n}=41(61.2 \%)$ & $\mathrm{n}=26(38.8 \%)$ & \\
\hline Hypertension ${ }^{\#}(\mathrm{mmHg})$ & & & $\mathbf{0 . 0 0 * , b}$ \\
\hline Exists & $\mathrm{n}=9(29.0 \%)$ & $\mathrm{n}=22(71.0 \%)$ & \\
\hline Absent & $\mathrm{n}=36(61.0 \%)$ & $\mathrm{n}=23(39.0 \%)$ & \\
\hline Type 2 diabetes & & & $\mathbf{0 . 0 0 * , \mathbf { b }}$ \\
\hline Exists & $\mathrm{n}=6(25.0 \%)$ & $\mathrm{n}=18(75.0 \%)$ & \\
\hline Absent & $\mathrm{n}=39(59.1 \%)$ & $\mathrm{n}=27(40.9 \%)$ & \\
\hline Family History $\# \#$ & & & $\mathbf{0 . 0 2} *, \mathrm{~b}$ \\
\hline Absent & $\mathrm{n}=40(56.3 \%)$ & $\mathrm{n}=31(43.7 \%)$ & \\
\hline Exists & $\mathrm{n}=5(26.3 \%)$ & $\mathrm{n}=14(73.7 \%)$ & \\
\hline
\end{tabular}

*BMI: Body mass index; **BSA: body surface area; \#Hypertension: systolic $\geq 140$, diastolic $\geq 90$ millimeter mercury; \#\#Family history: coronary artery disaese. *The bold values show statistical significance $(p<0.05)$. Differences between groups were analysed by Student's $t$-test for numerical variables, and with (a) Fisher's exact test and (b) Pearson's chi-square $\left(\chi^{2}\right)$ test for categorical variables.

(Table III). The small sample size may have accounted for these results.

\section{Discussion}

CVD (mainly cardiac disease and stroke) accounting for 17 million deaths, is a leading cause of death. Although CVDassociated deaths arise most frequently at older ages, almost $45 \%$ of them are seen in people under the age of 70 (2). According to the 2018 Health Statistics of WHO, deaths of NCD in 2016, an estimated 41 million deaths occurred due to noncommunicable diseases (NCDs), comprised $71 \%$ of a total of 57 million deaths. A total of 17.9 million of these ( $44 \%$ of all deaths caused by NCD) were the result of CVD (16).

The TEKHARF Study by Onat et al., which started in 1987 provides important data related to CVD in Turkey. In the TEKHARF 2014 Study, it was reported that 340.000 adults die per year in our country and there are 420.000 new coronary heart disease (CHD) cases per year (17). In the same study it was reported that the mortality rate due to CHD among 45-74 year-old-individuals is 2-4 fold higher compared to other European countries (17). Abnormalities in lipoprotein metabolism account for $50 \%$ of the risks that
Table II. CETP polymorphism and allele distributions (CETP, $C>T$ ) of groups.

\begin{tabular}{lccc}
\hline Genotype & $\begin{array}{c}\text { Control } \\
\text { group }(\mathrm{n}=45)\end{array}$ & $\begin{array}{c}\text { CADP } \\
\text { group }(\mathrm{n}=45)\end{array}$ & $p$-Value \\
\hline $\mathrm{CC}$ & $\mathrm{n}=41(91.1 \%)$ & $\mathrm{n}=40(88.9 \%)$ & 1.00 \\
$\mathrm{CT}$ & $\mathrm{n}=4(8.9 \%)$ & $\mathrm{n}=5(11.1 \%)$ & 1.00 \\
$\mathrm{TT}$ & $\mathrm{n}=0(0.0 \%)$ & $\mathrm{n}=0(0.0 \%)$ & n.c. \\
\hline Allele & \multicolumn{2}{c}{ Allele distribution } & \\
\hline $\mathrm{C}$ & $86(95.5 \%)$ & $85(94.4 \%)$ & n.c. \\
$\mathrm{T}$ & $4(4.5 \%)$ & $5(5.6 \%)$ & 1.00 \\
\hline
\end{tabular}

CADP: Coronary artery disease patient; n.c.: not computed.

contribute to the development of CVD. During the last decade, despite improvements in the management of CVD, new $\mathrm{CV}$ risk factors have been studied in order to prevent these diseases (18). In a genetic study by Hsu et al., aiming at defining novel risk factors, the association between genetic variations in the CETP gene and HDL-cholesterol levels among the Taiwanese and Chinese population was investigated (19). Evidence was presented indicating that 
Table III. The demographical data of groups according to CETP Polymorphism.

\begin{tabular}{|c|c|c|c|c|c|c|c|}
\hline \multirow[t]{2}{*}{ Demographical data } & \multicolumn{2}{|c|}{ Genotype } & \multirow[b]{2}{*}{$p$-Value } & \multirow[b]{2}{*}{ Allele C } & \multirow[b]{2}{*}{$p$-Value } & \multirow[b]{2}{*}{ Allele T } & \multirow[b]{2}{*}{$p$-Value } \\
\hline & $\mathrm{CC}$ & $\mathrm{CT}$ & & & & & \\
\hline Smoking & & & 1.00 & & n.c. & & 1.00 \\
\hline Smokers & $\mathrm{n}=41(91.1 \%)$ & $\mathrm{n}=4(8.9 \%)$ & & $\mathrm{n}=45(50 \%)$ & & $\mathrm{n}=4(8.9 \%)$ & \\
\hline Non-smokers & $\mathrm{n}=40(88.9 \%)$ & $\mathrm{n}=5(11.1 \%)$ & & $\mathrm{n}=45(50 \%)$ & & $\mathrm{n}=5(11.1 \%)$ & \\
\hline Statin & & & 0.43 & & n.c. & & 0.43 \\
\hline Users & $\mathrm{n}=22(95.7 \%)$ & $\mathrm{n}=1(4.3 \%)$ & & $\mathrm{n}=23(100 \%)$ & & $\mathrm{n}=1(4.3 \%)$ & \\
\hline Non-users & $\mathrm{n}=59(88.1 \%)$ & $\mathrm{n}=8(11.9 \%)$ & & $\mathrm{n}=67(100 \%)$ & & $\mathrm{n}=8(11.9 \%)$ & \\
\hline $\begin{array}{l}\text { Hypertension } \# \\
(\mathrm{mmHg})\end{array}$ & & & 1.00 & & n.c. & & 1.00 \\
\hline Exist & $\mathrm{n}=28(90.3 \%)$ & $\mathrm{n}=22(70.96 \%)$ & & $\mathrm{n}=31(100 \%)$ & & $\mathrm{n}=3(9.7 \%)$ & \\
\hline Absent & $\mathrm{n}=53(89.8 \%)$ & $\mathrm{n}=23(38.98 \%)$ & & $\mathrm{n}=59(100 \%)$ & & $\mathrm{n}=6(10.2 \%)$ & \\
\hline Type2 diabetes & & & 1.00 & & n.c. & & 1.00 \\
\hline Exist & $\mathrm{n}=22(91.7 \%)$ & $\mathrm{n}=2(8.3 \%)$ & & $\mathrm{n}=24(100 \%)$ & & $\mathrm{n}=2(8.3 \%)$ & \\
\hline Absent & $\mathrm{n}=59(89.4 \%)$ & $\mathrm{n}=7(10.6 \%)$ & & $\mathrm{n}=66(100 \%)$ & & $\mathrm{n}=7(10.6 \%)$ & \\
\hline Family history \#\# & & & 0.67 & & n.c. & & 0.67 \\
\hline Exist & $\mathrm{n}=18(94.7 \%)$ & $\mathrm{n}=1(5.3 \%)$ & & $\mathrm{n}=19(100 \%)$ & & $\mathrm{n}=1(5.3 \%)$ & \\
\hline Absent & $\mathrm{n}=63(88.7 \%)$ & $\mathrm{n}=8(11.3 \%)$ & & $\mathrm{n}=71(100 \%)$ & & $\mathrm{n}=8(11.3 \%)$ & \\
\hline
\end{tabular}

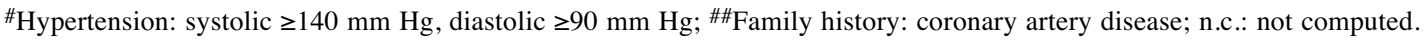

genetic variations in the CETP gene locus may bring about significant differences at HDL-cholesterol levels (19).

In contrast to the literature (20), our comparison of the HDL-risk score, which reflects the ratio of total cholesterol to HDL-cholesterol, indicated that the mean values of HDLrisk scores of men $(4.95 \pm 1.22, \mathrm{n}=61)$ and women $(4.96 \pm 1.55$, $\mathrm{n}=29$ ) were similar and there was no statistically significant difference between the groups $(p<0.96)$. The absence of statistically significant differences may be due to the insufficient number of participants. In the study of UjcicVoortman et al., it was observed that HDL-risk levels of both Turkish men and women were higher than in Dutch individuals and there was a statistically significant difference between the groups ( $p<0.001$ and $p<0.01$, respectively) (20). The post-hoc analysis of COURAGE Trial, suggested that total cholesterol/HDL-cholesterol ratio was the best risk predictor (21). In addition, it showed that every unit of increase of HDL-risk level was associated with $53 \%$ increase in MI risk (22). Total cholesterol/HDL-cholesterol ratio is known as the aterogenci index and it is considered that its value as a CV risk predictor is higher than other risk factors, such as LDL (22). The value of this ratio is important especially when the lipid profile is within the normal limits. In this study, there was no statisticaaly significant association between the CETP gene polymorphism and smoking status $\left(p<1.00, \chi^{2}=0.12\right)$. The small number of participants may account for this result. In agreement, Hsu et al., did not find an association between CETP polymorphism and smoking (19). In another study the association of CETP polymporhism (Taq1B) among Turks and smoking was investigated (23). In the study by Hodoğlugil et al., the levels of HDL-cholesterol in individuals with the CETP gene Taq1B polymorphism were not statistically different between smokers and non-smokers (23). Contrary to our study and the study by Hodoğlugil et al., in another study by Devi et $a l$. on the CETP polymorphism $-629 \mathrm{C} / \mathrm{A}$, it was observed, that the number of smokers among patients who had atherosclerosis was higher than in controls and there was a significant difference between groups $(p<0.000)$ (24). Comparing the distribution of hypertension between the control group and the CADP group, it was observed that $71 \%(n=22)$ of CADP and $29 \%(n=9)$ of controls were hypertensive and the difference between groups was statistically significant $\left(p<0.00, \chi^{2}=8.31\right)$. In the study by Devi et al., it was observed that numbers of hypertensive individuals were higher in the disease group than in the control group and the difference was statistically significant $(p<0.005)(24)$. Considering the distribution of lipid levels, although there was no statistically significant difference $(p<0.13)$, it was observed that the levels of HDL-cholesterol which are considered as atheroprotective, were higher among the individuals in the control group $(40.27 \pm 8.33, \mathrm{n}=45)$ than in the CADP group $(37.80 \pm 7.22, n=45)$. Comparing all participants' (healthy controls and CADP groups) demographical data in our study according to the CETP gene polymorphism genotype and alleles, there was no statistically significant difference between the groups regarding age, gender, weight, BMI and BSA (respectively $p<0.30, p<1.00$, 
$p<0.21, p<0.90, p<0.52, p<0.63)$. In the study of Ruan et $a l$. , it was determined that the individuals in the group with the Taq1B CETP gene polymorphism, who had BMI higher than $27 \mathrm{~kg} / \mathrm{m}^{2}$ had higher levels of HDL-cholesterol than the individuals in the healthy control group whose BMI was equal or less than $24 \mathrm{~kg} / \mathrm{m}^{2}$ (25). It was observed that when BMI was higher than $30 \mathrm{~kg} / \mathrm{m}^{2}$, the increase in HDLcholesterol levels was more prominent, and it was concluded that the Taq1B polymorphism interacts with $\mathrm{TG}$ in modulating HDL-cholesterol levels partly independently from BMI. In the same study, it was observed that in the obese group (BMI $>27 \mathrm{~kg} / \mathrm{m}^{2}$ ), HDL-cholesterol levels were lower and TG levels were higher than those in the normal control group (BMI $\leq 24 \mathrm{~kg} / \mathrm{m}^{2}$ ) and the difference was statistically significant (for both variables $p<0.01)(25)$. In our study, it was observed that the means of BMI, systolic and diastolic blood pressures and total cholesterol levels in the CADP group were significantly higher than in the control group (respectively $p<0.004$ and $p<0.001$ ). In addition, there was a statistically significant difference between the groups according to smoking status $(p<0.003)$.

In the study of İsbir et al., considering the genotype and allele distribution, it was observed that the M1 allele and $\mathrm{MspM}_{1} \mathrm{M}_{1}$ genotype were higher in the CADP group than in the healthy control group $(p<0.001)(26)$. CVD risks of people who have vascular disease have persisted despite cholesterol lowering therapies (especially statin treatment) (26). Therefore, novel substances sought to decrease the risk of CVD and CEPT inhibitors carry significant promise. The results of the REVAEL study on the use of anacetrabip (27), showed that the incidence of major coronary events in anacetrabip users among atherosclerotic cardiac patients who received intense statin therapy, were lower than placebo users (27). In a meta-analysis which examined nine different case-control studies and assessed the association of seven functional polymorphisms on the CETP gene and MI risk, it was shown that $C E T P$ gene polymorphisms were associated with increased MI risk especially among caucasians (28). This study revealed that CETP polymorphisms may be potential biomarkers for early MI diagnosis.

\section{Conclusion}

Considering the demographical data, it was observed that BMI as a numeric variable, the incidence of hypertension and type 2 diabetes, which are major risk factors of $\mathrm{CAD}$, and family history, were higher in the CADP group compared to healthy control group. Comparing groups according to gender, it was noteworthy that the number of smoker women in the CADP group was higher than in healthy controls, whilst HDL-cholesterol levels in men were lower. Regarding the association between CETP polymorphism, HDL and LDL sub-fractions and CAD, the results are consistent.

\section{Conflicts of Interest}

The Authors report no conflicts of interest regarding this study.

\section{Authors' Contributions}

Güliz Dirimen Arıkan: study design, writing of manuscript; Selim İsbir: recruitment of study participants and clinical investigation, data collection; Seda Güleç Yılmaz: statistical analysis, study design; Turgay İsbir: first draft, study design, approval of the final version.

\section{References}

1 Gaziano TA: Cardiovascular disease in the developing world and its cost-effective management. Circulation 112(23): 3547-3553, 2005. PMID: 16330695, DOI: 10.1161/CIRCULATIONAHA. 105.591792

2 Beaglehole R, Reddy S and Leeder SR: Poverty and human development. The global implications of cardiovascular disease. Circulation 116(17): 1871-1873, 2007. PMID: 17965400, DOI: 10.1161/CIRCULATIONAHA.107.736926

3 Schoen JF and Mitchell NR: The Heart. In: Robbins and Cotran, Pathological Basis of Disease. Kumar V, Abbas A, Fausto N and Aster CJ (eds.). Philadelphia, PA. 8th ed. Saunders Elsevier Company, pp. 530-545, 2010.

4 World Health Organization (WHO), The atlas of heart disease and stroke. Available from: http://www.who.int/gho/ncd/en/. Last accessed on 18th September 2016.

5 World Health Organization (WHO), World health statistics 2015, Part II. Global health indicators. Table 2. Cause-specific mortality and morbidity, 2015; 68. Available from: http://apps.who.int/iris/bitstream/10665/170250/1/978924069443 9_eng.pdf. Last accessed on 22th September 2016.

6 Tokgözoğlu L and Barış Kaya E: Atherosclerotic vascular disease and risk factors in Turkey: from past to present. J Atheroscler Thromb 15(6): 286-291, 2008. PMID: 19075493.

7 Oliveira HCF and de Faira EC: Cholesteryl ester transfer protein: the controversial relation to atherosclerosis and emerging new biological roles. IUBMB Life 63(4): 248-257, 2011. PMID: 21488146, DOI: 10.1002/iub.448

8 Thompson JF, Wood LS, Pickering EH, Dechairo B and Hyde CL: High-density genotyping and functional SNP localization in the CETP gene. J Lipid Res 48(2): 434-443, 2008. PMID: 17108362, DOI: 10.1194/jlr.M600372-JLR200

9 Boekholdt SM and Thompson JF: Natural genetic variation as a tool in understanding the role of CETP in lipid levels and disease. J Lipid Res 44(6): 1080-1093, 2003. PMID: 12639975, DOI: 10.1194/jlr.R200018-JLR200

10 Kallend D: CETP, human genome and cardiovascular outcomes. Swiss Med Weekly 140(21-22): 294-296, 2010. PMID: 20512706, DOI: smw-12994

11 Yılmaz H, İsbir T, Ağaçhan B and Karaali ZE: Effects of cholesterol ester transfer protein Taq1B gene polymorphism on serum lipid levels in Turkish coronary disease patients. Cell Biochem Funct 23(1): 23-28, 2005. PMID: 15386541, DOI: $10.1002 / \mathrm{cbf} .1124$

12 Durrington PN: Cholesteryl ester transfer protein (CETP) inhibitors. Brit J Cardiol 19: 126-33, 2012. DOI: 10.5837/ bjc.2012.024. 
13 Glew RH: Lipid Metabolism 22, Pathways of metabolism of special lipids. In: Textbook of Biochemistry, With Clinical Correlations. Devlin T.M. (ed.). India. 7th ed. MPS Limited, A Macmillan Company, John Wiley \& Sons, Inc. 724, 2011.

$14 \mathrm{Li} \mathrm{X}, \mathrm{Wu}$ Y, Zhang L, Cao Y, Li Y, Li J, Zhu L and Wu G: Comparison of three common DNA concentration measurement methods. Anal Biochem 451: 18-24, 2014. PMID: 24495734, DOI: $10.1016 /$ j.ab.2014.01.016

15 Mhlanga MM and Malmberg L: Using molecular beacons to detect single-nucleotide polymorphisms with real-time PCR. Methods 25(4): 463-471, 2001. PMID: 11846616, DOI: $10.1006 /$ meth.2001.1269

16 World Health Organization (WHO), World health statistics 2018, Part II. Status of the health-related SDGs. Available from: https://apps.who.int/iris/bitstream/handle/10665/272596/9789241 565585-eng.pdf?ua=1. Last accessed on 19th February 2019.

17 Onat A, Karakoyun S, Akbaş T, Özpamuk Karadeniz F, Karadeniz Y, Çakır H, Şimşek B and Can G: TEKHARF Turkish Adult Risk Factor survey 2014: Overall mortality and coronary disease incidence in Turkey's geographic regions. Arch Turk Soc Cardiol 43(4): 331-332, 2015. DOI: $10.5543 /$ tkda.2015.80468

18 Ross R: Atherosclerosis - an inflammatory disease. N Engl J Med 340(2): 115-126, 1999. PMID: 9887164, DOI: 10.1056/ NEJM199901143400207

19 Hsu LA, Ko YL, Hsu KH, Ko YH and Lee YS: Genetic variations in the cholesteryl ester transfer protein gene and highdensity lipoprotein cholesterol levels in Taiwanese Chinese. Hum Genet 110(1): 57-63, 2002. PMID: 11810297, DOI: 10.1007/s00439-001-0640-z

20 Ujcic-Voortman J, Bos G, Baan CA, Uitenbroek DG, Verhoeff AP and Seidell JC: Ethnic differences in total and HDL cholesterol among Turkish, Moroccan and Dutch ethnic groups living in Amsterdam, the Netherlands. BMC Public Health 10: 740, 2010. PMID: 21118503, DOI: 10.1186/1471-2458-10-740

21 Acharjee S, Boden WE, Hartigan PM, Teo KK, Maron DJ, Sedlis SP, Kostuk W, Spertus JA, Dada M, Chaitman BR, Mancini GB and Weintraub WS: Low levels of high-density lipoprotein cholesterol and increased risk of cardiovascular events in stable ischemic heart disease patients: A post-hoc analysis from the COURAGE Trial (Clinical Outcomes Utilizing Revascularization and Aggressive Drug Evaluation). J Am Coll Cardiol 62(20): 1826-1833, 2013. PMID: 23973693, DOI: 10.1016/j.jacc.2013.07.051
22 Malaspina JP, Bussière $\mathrm{H}$ and Le Calve $\mathrm{G}$ : The total cholesterol/HDL cholesterol ratio: a suitable atherogenesis index. Atherosclerosis 40(3-4): 373-375, 1981. PMID: 7332616.

23 Hodoğlugil U, Williamson DW, Huang Y and Mahley RW: An interaction between the Taq1B polymorphism of cholesterol ester transfer protein and smoking is associated with changes in plasma high-density lipoprotein cholesterol levels in Turks. Clin Genet 68: 118-127, 2005. PMID: 15996208, DOI: 10.1111/ j.1399-0004.2005.00467.x

24 Devi A, Singh R, Dawar R and Tyagi S: Association of cholesteryl ester transfer protein (CETP) gene -629C/A polymorphism with angiographically proven atherosclerosis. Ind J Clin Biochem 32(2): 235-238, 2017. PMID: 28428701, DOI: 10.1007/s12291-016-0585-6

25 Ruan X, Ma L, Wang S, Lindpaintner K, Liu X, Wang B, Peng Z, Ma X, Cheng M, Zhang J, Liu L and Wang X: Association of two CETP polymorphisms with HDL levels in the Chinese obese population. Obesity 17(12): 2196-2201, 2009. PMID: 19444232 , DOI: $10.1038 /$ oby.2009.138

26 İsbir T, Yılmaz H, Ağaçhan B and Karaali ZE: Cholesterol ester transfer protein, apolipoprotein e and lipoprotein lipase genotype in patients with coronary artery disease in the turkish population. Clin Genet 64(3): 228-234, 2003. PMID: 12919138

27 REVEAL Collaborative Group, Bowman L, Chen E, Sammons E, Hopewell JC, Wallendszus K, Stevens W, Valdes- Marquez E, Wiviott S, Cannon CP, Braunwald E, Collins R and Landray MJ: Randomized Evaluation of the Effects of Anacetrapib through Lipid-modification (REVEAL) - A large-scale, randomized, placebo-controlled trial of the clinical effects of anacetrapib among people with established vascular disease: Trial design, recruitment, and baseline characteristics. Am Heart J 187: 182190, 2017. PMID: 28454801, DOI: 10.1016/j.ahj.2017.02.021

28 Wang Q, Zhou SB, Wang LJ. Lei MM, Wang Y, Miao C and Jin YZ: Seven functional polymorphisms in the CETP gene and myocardial infarction risk: A meta-analysis and meta-regression. PLoS ONE 9(2): e88118, 2014. PMID: 24533069, DOI: 10.1371 /journal.pone. 0088118

Received January 21, 2019

Revised February 16, 2019

Accepted February 25, 2019 